\title{
Commentary
}

\section{The impact of COVID-19 imposed lockdown in India in 2020}

\author{
Chandar Sahanaa ${ }^{1}$, Yuvaraja Murugan ${ }^{2 *}$ \\ ${ }^{1}$ Department of Community Medicine, ${ }^{2}$ Department of Orthopaedics, Pondicherry Institute of Medical Sciences, \\ Pondicherry, India
}

Received: 19 May 2021

Revised: 16 June 2021

Accepted: 18 June 2021

\section{*Correspondence:}

Dr. Yuvaraja Murugan,

E-mail: mrgn.yuvaraja@gmail.com

Copyright: () the author(s), publisher and licensee Medip Academy. This is an open-access article distributed under the terms of the Creative Commons Attribution Non-Commercial License, which permits unrestricted non-commercial use, distribution, and reproduction in any medium, provided the original work is properly cited.

\section{INTRODUCTION}

The World Health Organization (WHO) declared COVID19 pandemic as public health emergency of international concern (PHEIC) on January 30, 2019. ${ }^{1}$ Lockdown was introduced as a preventive strategy to reduce the community transmission of the severe acute respiratory syndrome corona virus 2 (SARS CoV-2). On 25th March 2020, Prime Minister on India announced countrywide lockdown. Measures like social distancing, restriction of mass gathering, closure of educational institutions, wearing face mask, hand hygiene etc. were greatly advertised to create awareness and bring about a behavior change. This paper throws light into some unseen circumstances and challenges faced during the COVID-19 pandemic imposed lockdown.

\section{Socio-economic and healthcare crises}

Nation-wide lockdown has not only led to financial crises among all social class people of the country but also major lag in nutrition status and healthcare of the population. These crises halt the successes gained in the previous years by the effective functioning of the national health programs. $^{2}$

\section{Plight of migrants}

Usually, migrant workers, laborers from rural India migrate to urban cities looking for opportunities, livelihood and better standard of living. The lockdown has severely affected not only their employment, income, food and uncertain future but also the movement of people.
With road and railway links suspended, walking back home was the only option left to reunite with their families. $^{3,4}$

\section{Mental health of women during the lockdown}

Lockdown has posed abrupt disruption among the family communication pattern, parental working style, household chores and art of parenting towards children. Closure of daycares, schools, offices and work from home for nonessential services has caused increased stress level among working women as well. Women being on the receiving end of things have shown increased anxiety, stress and depression symptoms during the lockdown compared to men. Women being the marginalized section of our society, needs immediate attention for this impact on mental health. ${ }^{5,6}$

\section{Technology that saves patients}

Preventive measures against the pandemic should protect the people from the dual burden of non- communicable and communicable diseases. Virtual reality played a very beneficial role in telemedicine, by creating awareness, taking preventive measures against contagious diseases, and even guiding through treatment of diseases. Live video streaming, also helped in improving the surveillance system of the ongoing situation.?

Newer innovative technologies like internet of medical things (IoMT) has paved a way forward in treating orthopedic patients during the ongoing COVID-19 pandemic. $^{8}$ 


\section{Virtual classes - a stressful classroom for teachers and students}

Online classes for school students has increased the stress of teaching among teachers. Holding the attention of young children continuously during online class is a great challenge. However, the true essence of walking through the classroom and interacting with the students is greatly missed. ${ }^{9}$ While students greatly miss the school environment while spending more time online, increased screen time in children has always been a concern. 'Pragyata' new guideline by Union Human Resource Department recommends maximum screen time of three hours per day. ${ }^{10}$

\section{Rise in internet usage}

India's internet usage rose by $13 \%$ since lockdown, the daily average consumption in this period was $9 \%$ higher, says Telecom department. ${ }^{11}$ The daily data usage was as high as $18 \mathrm{~GB}$ data per day during lockdown. ${ }^{12}$

\section{Lockdown was a blessing!}

Couples who were on infertility treatment managed to conceive naturally on their own. Lifestyle changes, freedom from stress of work, spending quality time between couples, abstinence from certain addictions due to non- availability were few healthy behavioral changes which helped to tune the biological clock. ${ }^{13,14}$ In short, a stress free life was all, it required.

\section{Other survivors in the ecosystem}

There seem to be positive impact on animals and birds during lockdown unlike in case of humans. Limited human interference and reduction in the pollution levels have helped them to reclaim their space in the ecosystem like the partial migratory birds having extended their stay little longer. ${ }^{15}$

\section{CONCLUSION}

The pandemic imposed lockdown, to some extent has helped in prevention and control of infectious diseases. However, it is time to address other newly adapted lifestyle changes and rising burden of mental health issues.

\section{REFERENCES}

1. Timeline: WHO's COVID-19 response. Available at: https://www.who.int/emergencies/diseases/novelcoronavirus-2019/interactive-timeline. Accessed on 07 November 2020.

2. Gopalan HS, Misra A. COVID-19 pandemic and challenges for socio-economic issues, healthcare and National Health Programs in India. Diabetes Metab Syndr. 2020;14(5):757-9.

3. Iyengar KP, Jain VK. COVID-19 and the plight of migrants in India. Postgraduate Medical Journal.
2020. Available at: https://pmj.bmj.com/content /early/2020/08/12/postgradmedj-2020-138454. Accessed on 27 November 2020.

4. The migrant worker crisis needs a multipronged response - analysis - Hindustan Times. Available at: https://www.hindustantimes.com/analysis/themigrant-worker-crisis-needs-a-multiprongedresponse/story-NRCjV7PFFnjJTqlOpi8bYJ.html. Accessed on 07 November 2020.

5. Gopal A, Sharma AJ, Subramanyam MA. Dynamics of psychological responses to COVID-19 in India: A longitudinal study. PlOs One. 2020;15(10):e0240650.

6. Lock down Locked within: A close look at the shadow pandemic and women's mental health Times of India. The Times of India. Available at: https://timesofindia.indiatimes.com/life-style/healthfitness/de-stress/lock-down-locked-within-a-closelook-at-the-shadow-pandemic-and-womens-mentalhealth/articleshow/78515757.cms. Accessed on 27 November 2020.

7. Singh RP, Javaid M, Kataria R, Tyagi M, Haleem A, Suman R. Significant applications of virtual reality for COVID-19 pandemic. Diabetes Metab Syndr. 2020;14(4):661-4.

8. Pratap Singh R, Javaid M, Haleem A, Vaishya R, Ali S. Internet of Medical Things (IoMT) for orthopaedic in COVID-19 pandemic: Roles, challenges, and applications. J Clin Orthop Trauma. 2020;11(4):7137.

9. Stress-filled life for teachers at virtual classes | Madurai News - Times of India. The Times of India. Available at: https://timesofindia.indiatimes.com/ city/madurai/stress-filled-life-for-teachers-at-virtualclasses/articleshow/77176412.cms. Accessed on 27 November 2020.

10. Maximum screen time should be 3 hours per day for online classes: HRD Ministry. The Times of India. 2020. Available at: https://timesofindia.indiatimes. com/life-style/parenting/teen/maximum-screentime-should-be-3-hours-per-day-for-online-classeshrd-ministry/photostory/77002800.cms. Accessed on 27 November 2020.

11. India's internet consumption up during Covid-19 lockdown, shows data [Internet]. Hindustan Times. 2020. Available at: https://www.hindustantimes.com /india-news/india-s-internet-consumption-up-duringcovid-19-lockdown-shows-data/story-

ALcov1bP8uWYO9N2TbpPIK.html. Accessed on 27 November 2020.

12. How India managed biggest data surge during Covid19 lockdown? DATAQUEST. 2020 Available at: https://www.dqindia.com/india-managed-biggestdata-surge-covid-19-lockdown/. Accessed on 27 November 2020.

13. Lockdown helped some couples on infertility treatment conceive naturally | Bengaluru News Times of India. The Times of India. Available at: https://timesofindia.indiatimes.com/city/bengaluru/l ockdown-helped-some-couples-on-ivf-treatment- 
conceive-naturally/articleshow/77918669.cms.

Accessed on 27 November 2020.

14. Pune: Noticeable rise in natural pregnancies during lockdown baffles IVF experts | Pune News - Times of India. The Times of India. Available at: https://timesofindia.indiatimes.com/city/pune/punenoticeable-rise-in-natural-pregnancies-duringlockdown-baffles-ivf-experts/articleshow/75795453 .cms. Accessed on 27 November 2020.

15. Narayani P. Pandemic-induced lockdown gives migratory birds and animals a reason to cheer. The Hindu. 2020. Available at: https://www.thehindu. com/news/national/tamil-nadu/pandemic-inducedlockdown-gives-migratory-birds-and-animals-areason-to-cheer/article31458071.ece. Accessed on 27 November 2020.

Cite this article as: Sahanaa C, Murugan Y. The impact of COVID-19 imposed lockdown in India in 2020. Int J Community Med Public Health 2021;8:3728-30. 